\author{
原 著 論 文 \\ 新潟県東頸城郡北部地域の椎谷期一西山期の \\ 砂岩の発達およびその石油地質学的考察* \\ その 2. 砂岩の貯留岩としての性質 \\ 本座栄 一** \\ （昭和 40 年 1 月 12 日受理）
}

\title{
Sedimentological and Oil-Geological Considerations on the Sandstones of the Shiiya and the Nishiyama Stages in the Northern Part of Higashikubiki, Niigata Prefecture
}

Part 2, Characters of the Sandstones as Reservoir Rocks

By

Eiichi HoNZA

\begin{abstract}
The writer reported that the sandstones in this area were composed of material supplied from the topographical high place by mass flowes such as turbidity currents, and that thick sandstone developed in WNW-ESE and -SE directions decreasing thickness and turbulence from the central to the marginal (remote) area (Part 1, Jour. Jap. Assoc. Petrol. Techn., Vol. 30, No. 2, 1965).

Porosity of the sandstone decreases with increasing median diameter and standard deviation of grains, and with increasing bed thickness. Therefore sandstones in the marginal area are more porous than in the central area, but thier capacity as oil reservoir is large in both the central and the middle areas, and small in the marginal area.

Permeability of the sandstone decreases with decreasing porosity and increasing standard deviation of grain size, but has no relation to the median diameter. Permeability of the sandstone decreases when bed thickness increases, and the sandstones in the marginal area are more permeable than those in the central area.

Thus the sandstones in the middle area as well as in the central area are suitable for reservoirs, while those in the marginal area are more porous and permeable in spite of their thinness.

The sandstone fabrics control the directional permeability. Permeability of the sandstone is maximum in the direction parallel to the current flow which carried sand grains at the time of deppsition and minimum in the direction perpendicular to bedding plane.

It is concluded that these characters should be taken into consideration in petroleum exploration and exploitation works.
\end{abstract}

* 一部は石油技術協会総会個人講演で発表 (1964)

** 東京大学海洋研究所 


\section{1 緒言}

筆者は本論文の“その 1”（石技誌，30 巻，2号，1965） で新潟県東頸城郡北部一带に発達する椎谷期西山期の砂 岩の geometry・堆積機構・成因な゙について述へ，本 地域の砂岩が地形的に高所より低所に turbidity current などの一種の mass frow により供給され, 西北西一東 南東ないし南東方向に厚く堆積し, その流れの主流にお いて砂の堆積は厚く, かつ大きく乱れ, その拡がりとし て周辺部においては比較的穏やかに堆積したことを明ら かにした。

本論文ではこのような砂岩が貯留岩となった時いかな る性質（孔隙率・浸透率）をもつかという問題をとりあ げ，採集した試料を種々の地質学的要因と照らし合せて 調へた結果を述べ，地下に扔ける貯留岩の性質を判断す る上での基礎的資料を提供してみたいと思う。

人為的に各種の径の砂粒を配合し，それを基にして孔 隙率・浸透率に影響を与える要素を検討した報告は従来 かなりあるが，自然の砂岩の孔隙率・浸透率を調へ，そ れと地質学的要因を結びつけて検討した報告は少ない。 したがって今日まで報告されている人為的モデル実験に おける結果を基にして，実際の砂岩における地質学的諸 要素と貯留岩としての性質との関連性を検討してみたい と思う。

\section{2 孔隙率からみた本地域の砂岩}

ここで取り扱った試料は本論文の“その 1 ”で使用し たものと同一の試料から取った。孔隙率の测定には Ruska high-pressure porosimeter を使用し，120 気圧の もとで水銀圧入を行ない測定した。孔隙率の測定值と砂 岩のもつ諸性質との相互関係を以下に検討してみよう。

\section{$2 \cdot 1$ 孔吵率亡中央粒径, sorting および細粒部含有 量亡の関係}

自然の岩石において孔吵率に影響を与える要素は粒 径, 粒度分布, 粒の形, 内部構造 (粒子の配列状態), compaction, cementation などである。粒径は理論的に は孔隍率に影響を与えない。しかしながら，実際の砂岩 においては粒径が変化すると粒子の shape が異なり， packing 状態が変化して，孔隙率に影響を与える ${ }^{5)}$ 。ま た種々の粒径の粒子があると孔隙部分がうめられ， packing 状態も変化し，孔隙率は減少する $\left.{ }^{3)}, 10\right) 。$ 砂岩の 内部構造は粒子の shape, 堆積課程の相違などに支配さ れる。また compaction, cementation をうけることによ り孔隙率は減少する4)。本地域の砂岩においいては，粒径 および粒度分布が孔隙率に与える影蠁について述べてみ よう。
一般に中央粒径が大きくなると孔陌率は減少する傾向 にある(第 1 図)。これは砂岩の粒子の sphericity が粒 径の増大にともない大きくなる傾向にあり，それにより 砂粒の packing 状態が密になり，孔隙率の減少をきた すためと考えられる えるあたりから孔隙率が大きく変化する様子がみられる が，これは粒径が大きくなったため packing 状態が変化 をきたしたためと考えられる。また，第 2 図のごとく， sorting が琹くなると孔隙率が減少する傾向がある。 silt 以下の粒径の含有量をもって細粒部の割合とすると, こ れは孔隙率とあまり明らかな相関関係を示さないが，細 粒部含有量が多くなると幾分孔隙率も大きくなる傾向も みられる(第 3 図)。これは中央粒径が小さくなると孔 隍率が増加する傾向と, 細粒部が増加すると sorting が 悪くなる傾向との, 孔陌率へのつの相反する影響が複合 した現われであると思われる。

Fig. 1 Relation between porosity and median diamteter of grains.

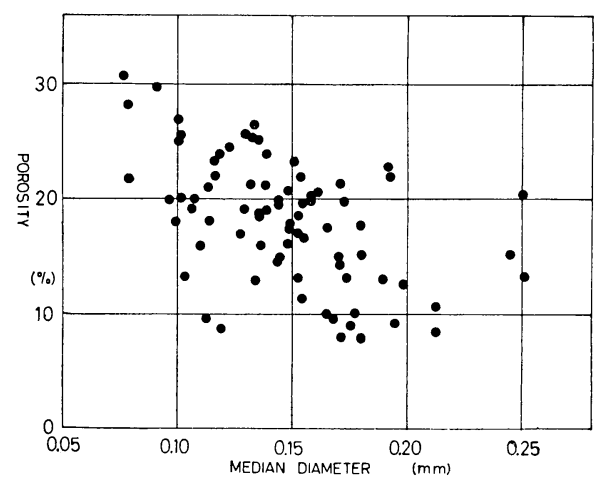

Fig. 2 Relation between porosity and phi standard deviation $\left(\sigma_{\phi}\right)$ of grains

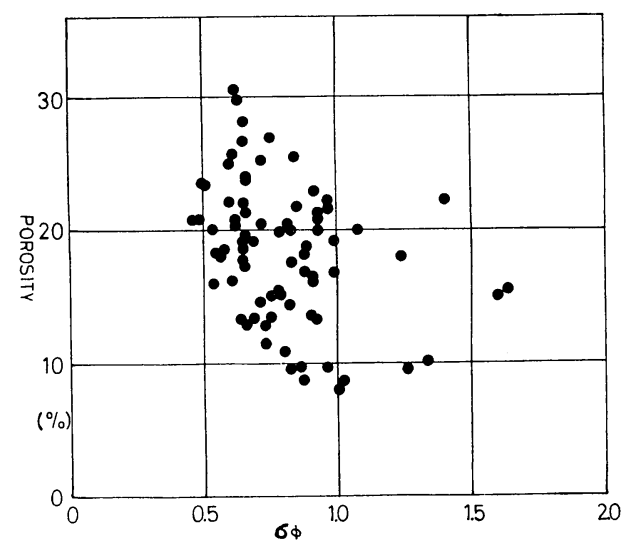


Fig. 3 Relation between porosity and fine grain contents (smaller than $4 \phi$ ).

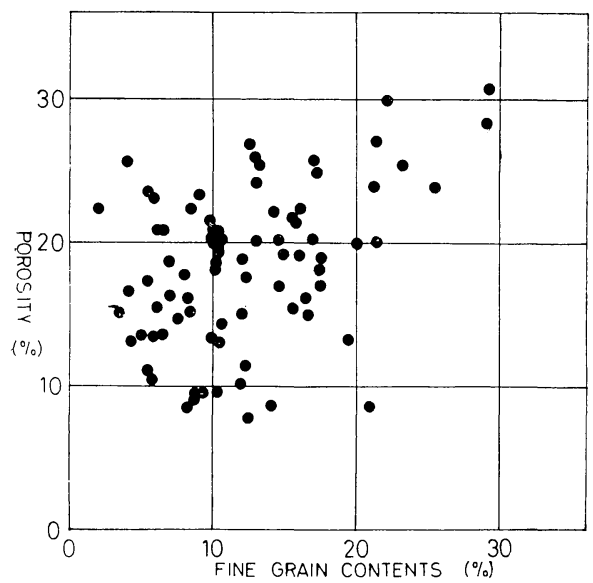

\section{$2 \cdot 2$ 孔隙率亡層厚との関係}

一般に砂岩単層が厚くなると孔隙率は減少する傾向が ある(第 4 図)。本論文の“その 1 ”で砂岩単層が厚く なると中央粒径は大きくなり， sorting が悪くなる傾向 があると述べた。中央粒径が大きくなり， sorting が悪 くなると孔隙率は減少することからも以上のことは予測 できる。また“その 1 ”で砂岩体の中心部の砂岩と述へ たものは一般に低い孔陌率であり，中間部，周辺部とい くにしたがい，高い孔隙率となる傾向がある。

今，砂岩の眝留岩としての大きさを相対的に知るため に第 4 図において, 砂岩体の中心部, 中間部, 周辺部の 砂岩群がそれぞれ， $A \cdot B \cdot C$ 直線上の孔隙率をもつも のと仮定し，野外において 1 地点の砂岩単層の厚さをで きるかぎり連続的に測定した結果より，貯留岩としての 大きさを検討してみょう。
Fig. 4 Relation between porosity and bed thickness.

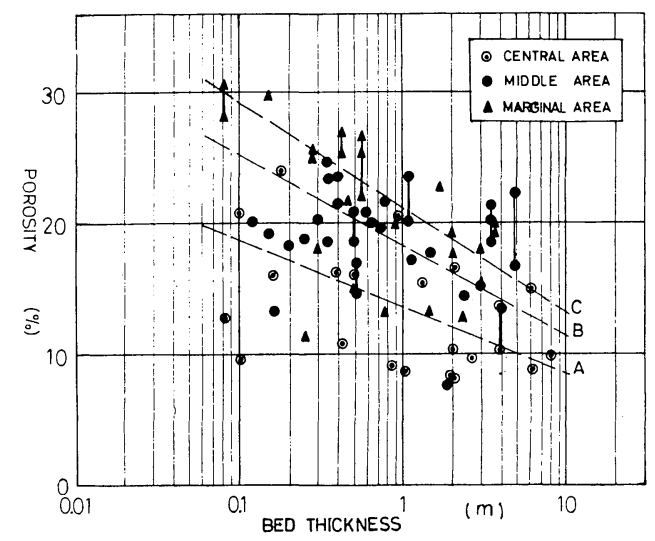

砂岩単層の層厚を $h$ ，孔隙率を $\phi$, 厚さを測定した砂 岩単層の数を $n, 1$ つの砂岩部層の砂岩全体の厚さと測 定した部分の愿さとの比率を $C_{r}: 1$ として,

$$
N=\sum_{i=1}^{n} h_{i} \phi_{i} \times C_{r}
$$

なる $N$ を，貯留岩としての容量の相対的大きさを知るた めの值とみなすことにして, 11 地点の $N$ の值を計算し たのが第 1 表である。

第 1 表をみると，一般に貯留岩としての容量は中心部 の砂岩群が最も大きい傾向があるが，中間部の砂岩群も それに劣らない位の大きさがある。周辺部の砂岩群は幾 分劣る傾向がみられるが，これは砂岩が周辺部で薄くな っていることが大きく影響している結果である。

\section{3 浸透率からみた本地域の砂岩}

以上において，貯留岩としての容量の面から検討して 第 1 表 Calculations of relative values of capacity as reservoirs.

\begin{tabular}{|c|c|c|c|c|c|c|}
\hline Depositional area & Locality & Member & $n$ & $\sum_{i=1}^{n} h_{i} \cdot \phi_{i}$ & $C_{r}$ & $N$ \\
\hline \multirow{4}{*}{ Central area } & Koyajima $^{1)}$ & $\mathrm{D}$ & 39 & 571 & $60 / 44$ & 786 \\
\hline & Miyanotsubo $^{2)}$ & $\mathrm{H}$ & 30 & 411 & 1 & 411 \\
\hline & Miyanotsubo & $\mathrm{D}$ & 27 & 396 & $40 / 32$ & 494 \\
\hline & Iriyama $^{3)}$ & $\mathrm{D}$ & 32 & 318 & $60 / 23$ & 816 \\
\hline \multirow{3}{*}{ Middle area } & Nyüba ${ }^{4)}$ & $\mathrm{D}$ & 61 & 297 & $35 / 14$ & 744 \\
\hline & Ishidani $^{5)}$ & $\mathrm{H}$ & 26 & 413 & $30 / 25$ & 502 \\
\hline & Ishidani & $\mathrm{D}$ & 26 & 292 & $25 / 10$ & 452 \\
\hline \multirow{4}{*}{ Marginal area } & Fujio $^{6)}$ & $\mathrm{H}$ & 18 & 223 & 1 & 223 \\
\hline & Fujio & $\mathrm{D}$ & 16 & 124 & $17 / 5$ & 418 \\
\hline & Ishiguro $^{7)}$ & $\mathrm{H}$ & 31 & 174 & 1 & $\begin{array}{l}410 \\
174\end{array}$ \\
\hline & Ishiguro & $\mathrm{D}$ & 33 & 224 & 1 & 224 \\
\hline
\end{tabular}

1）小谷息. 2）宫八坪、3）入山, 4）入場, 5）石谷, 6）藤尾，7）石黒 
きたが，次に浸透率について述へよう。

浸透率は，真鍮円筒管中に試料をパラフィンだ固 定 し，地層に水平な方向に流体が流れるようにととのえて 測定した。流体は一部食塩水を使った（後述）ほかは空 気を使用した。測定誤差は最大 $20 \%$ であり，これはパ ラフィンと試料との接着部分におけるものおよび試料作 成時における表面の孔隙部分の変化が大きな原因となっ ている。以下に浸透率と砂岩のもつ諸性質との相互関係 を検討してみよう。

\section{$3 \cdot 1$ 浸透率と孔陌率, 中央粒径, sorting 亡の関係}

砂の浸透率は Kozeny などにより孔隙率と tortousity と比表面積（あるいは粒径）との関数として単純に表わ されているが99, 自然の岩石においては粒度分布, 内部 構造, compaction, cementation などの要素があり, そ れらが孔隙率を支配するとともに，浸透率へ影響を与 え，実際にはきわめて複雑である。本地域の砂岩につい てこれらの要素の幾つかが浸透率へ及ぼす影響を述べて みよう。

孔隚率の堌加にともない，浸透率の対数は比例的に増 加する傾向がある（第 5 図）。これは他の油砂について 認められる一般的傾向と一致している。次に, 浸透率と 中央粒径との関係は, 第 6 図に示すように, 全く相関関 係が認められない。人工砂について実験を行なった Krumbein 等の報告 ${ }^{6)}$ によると, 浸透率は中央粒径の増 加にともない，その 2 乗に比例して増加すると述べてい る。これは粒径たけに着目し，そのほかの条件を一定と した時に得られたものであり，実際の砂岩においては前 述の諸要素が複雑にからみ合い，粒径との相互関係を打

Fig. 5 Relation between porosity and air permeability.

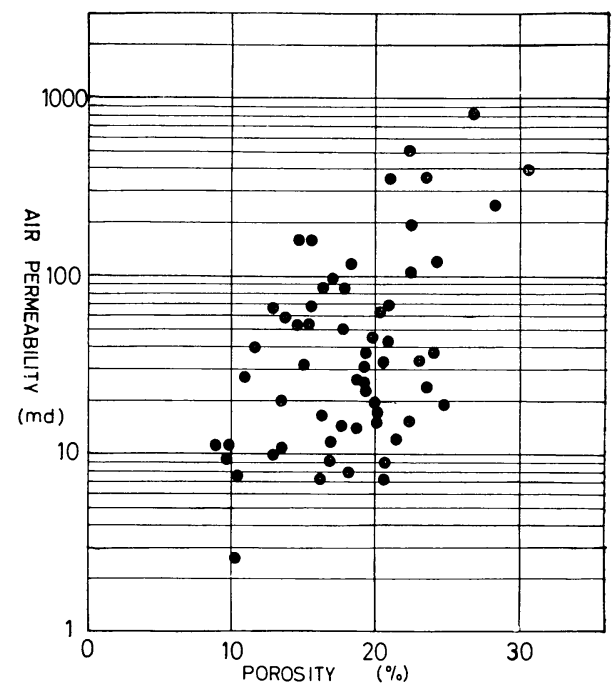

ち消しているためとみられる。また第 7 図のごとく，浸 透率は sorting が悪くなると減少する傾向がある。

\section{$3 \cdot 2$ 浸透率と層厚の関係}

一般に砂岩単層が厚くなると，明瞭ではないが，浸透 率は減少する傾向がある（第 8 図）。孔隙率の場合と同 様に，堆積の中心部の砂岩ほど浸透率の值は低く，周辺 部の砂岩ほど大きい值となる傾向がある。したがって第 1 表に掲げた貯留岩としての相対的容量と第 8 図の浸透 率の傾向とから，中心部の砂岩群に劣らず，あるいはそ れ以上に中間部の砂岩群が貯留岩として大きな価値をも

Fig. 6 Relation between air permeability and median diameter of grains.

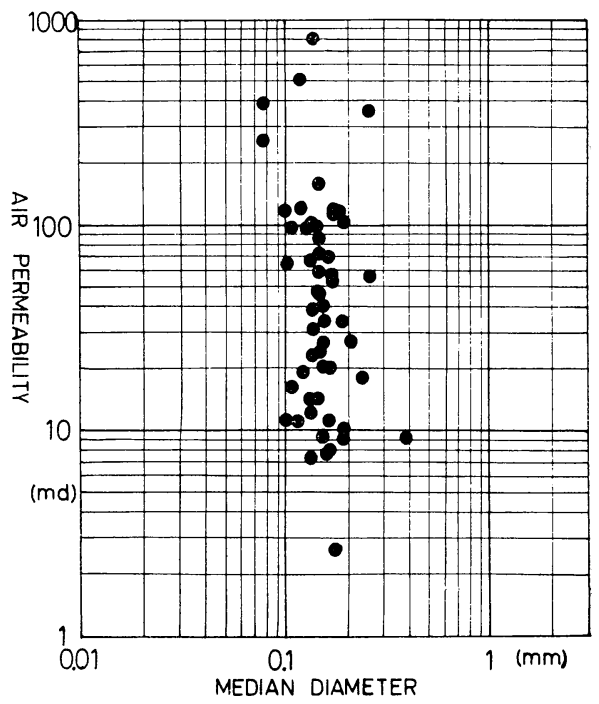

Fig. 7 Relation between air permeability and. phi standard deviation of grains.

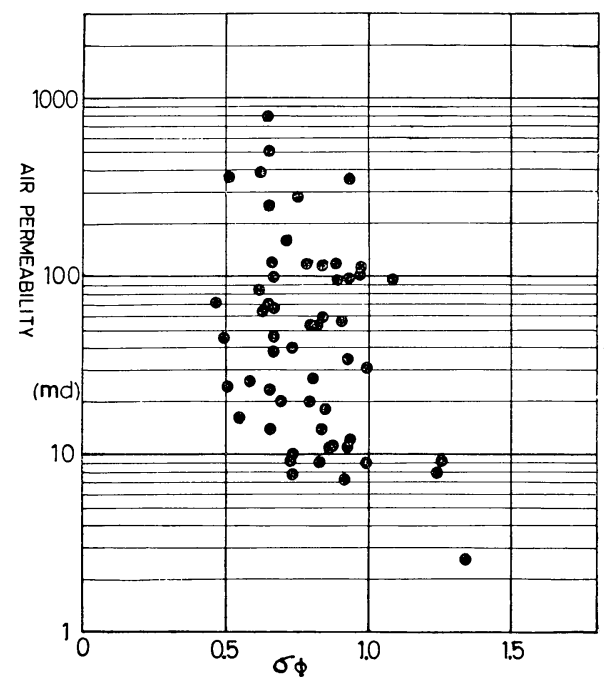


Fig. 8 Relation between air permeability and bed thickness.

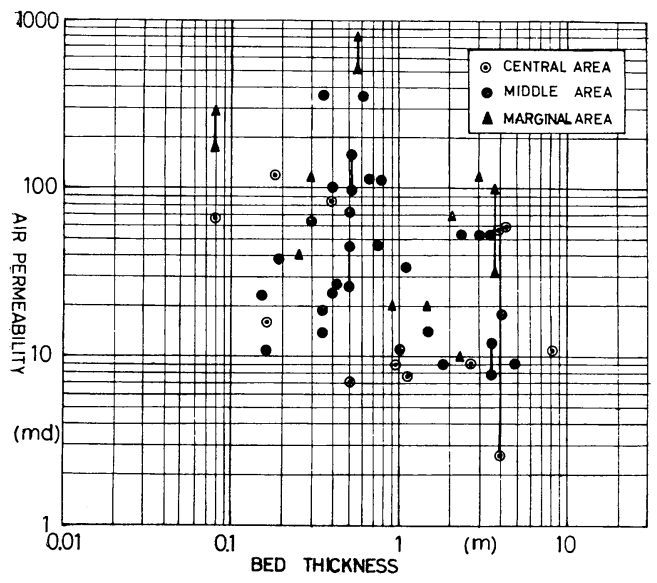

っているといえる。周辺部の砂岩群が全体として, 貯留 岩としての容量が小さいのは砂岩群全体の嬮さが薄いた めであり，このことを除けば，周辺部の砂岩の方が貯留 岩として良好な性質をそなえている。

\section{$3 \cdot 3$ 浸透率の方位性}

本論文の“その 1 ”において本地域の砂岩は一種の mass flow により堆積したものであり，一般に砂粒の配 列状態に規則性がみられると述べた。このような砂岩で は浸透率にも方位性があることが予想される7),81,11。第 2 表に本論文の “その 1 ”で掲げた 6 コの試料について current marking に示された堆積時の流れに平行方向 $(x)$, 成層面に平行で流れに直角方向 $(y)$, 成層面に直 角方向 $(z)$ の 3 方向で測定した浸透率の值を示してあ る。

第 2 表 Directional permeability (md.)

\begin{tabular}{|c|r|r|r|}
\hline Sample number & $K_{x}$ & $K_{y}$ & $K_{z}$ \\
\cline { 1 - 3 } I & 10 & 6 & 3 \\
II & 61 & 45 & 27 \\
III & 18 & 29 & 13 \\
IV & 16 & 12 & 7 \\
V & 30 & 15 & 7 \\
II & 29 & 13 & 12 \\
\hline
\end{tabular}

試料而を除いて他はすべて， $x$ 方向，つまり流れに平 行方向で浸透率は最大となり， $z$ 方向つまり成層面に直 角方向で最小となる。試料而は砂粒の配列状態が大きく 乱れているものであり，それが浸透率の方位性に強く反 映している。今，流れの方向を基準とした時の砂粒の長 軸方向の標準偏差值と, $x \cdot y$ 方向の浸透率の值の比を とった時の関係をみると, 第 9 図のごとく, 標準偏差佔
Fig. 9 Relation beween directional permeability ratio $\left(K_{x} / K_{y}\right)$ and standard deviation of grain orientations.

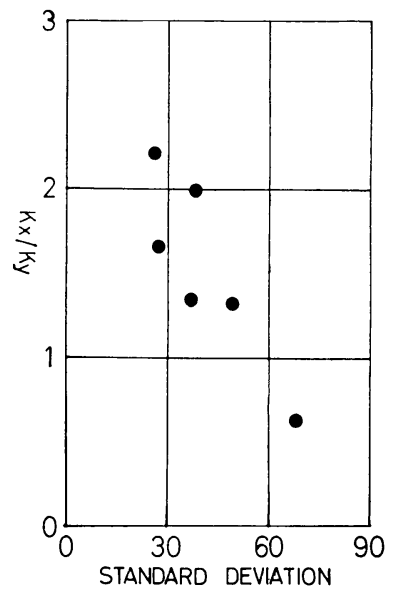

の小さいほど，つまり同一方向への配列の規則性がはっ きりみられる砂岩ほど， $x$ 方向の浸透率が $y$ 方向のそれ にくらべ，大きい値を示す傾向がある。これは砂粒の長 軸が砂を運んた流れの方向に平行に近く配列し，そのた め孔吵網の tortousity がその方向に最も小さくなってい るためと考えられる。

以上のことからわかるように，砂粒の配列状態にみら れる規則性と浸透率の間には密接な関係があり, 砂の堆 積時における流れの存在が砂粒の配列状態に方位性を与 え，それが浸透率に方位性を与えている。

\section{$3 \cdot 4$ 塩水浸透率}

以上空気浸透率について述へてきたが，塩水の場合の 性質を一部について行なった実験から述べてみよう。

測定には食塩水を使用し，7日間連続的に流した時大 体一定の浸透率の值となったので，その時の值を採用し た。それと細粒部含有量との関係を求めてみると, 第 10 四のごとく，細粒部含有量が多くなると一般に浸透 率の対数は反比例的に減少する傾向がみられる。また掹 水浸透率と空気浸透率の比も同様に細粒部含有量が多く なると減少する傾向がある（第 11 図）。したがって液 体による浸透率を組織的にみれば，以上述べてきたこと と多少異った結果も現われると思われるが，空気浸透率 測定でえられた各種の関係は, 塩水浸透率を用いても定 性的には大体成り立つと思われる。

\section{4 要約および結論}

本論文の“その 1 ”で述べたように，本地域の砂岩は 地形的に高所加ら低所へ一種の mass flow により供給さ れ, 西北西一東南東ないし南東方向に厚く堆積し, その 
Fig. 10 Relation betweensalt water permeability and fine grain contents (smaller than $4 \phi$ ).

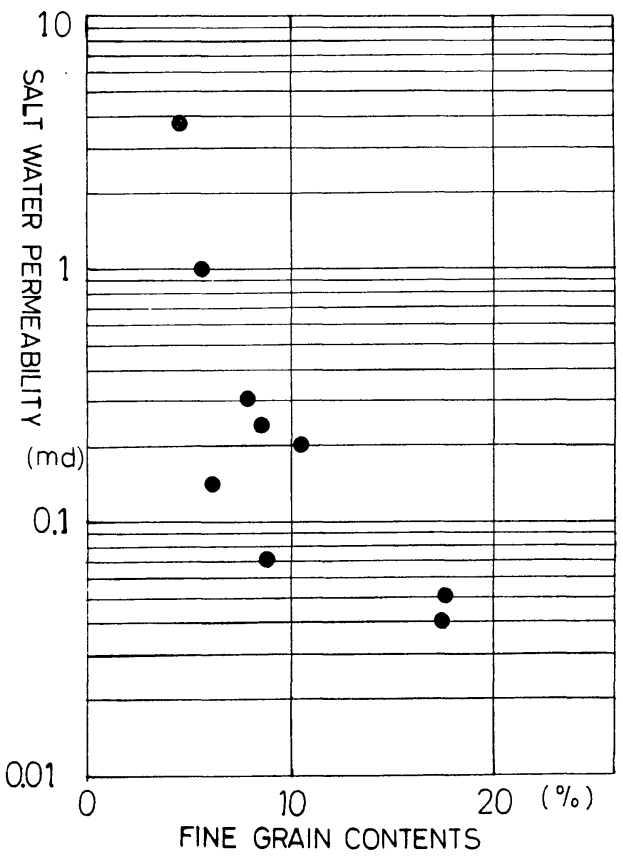

Fig. 11 Relation between salt water permeability-air permeability ratio $\left(K_{x} / K_{a}\right)$ and fine grain contents (smaller than $4 \phi$ ).

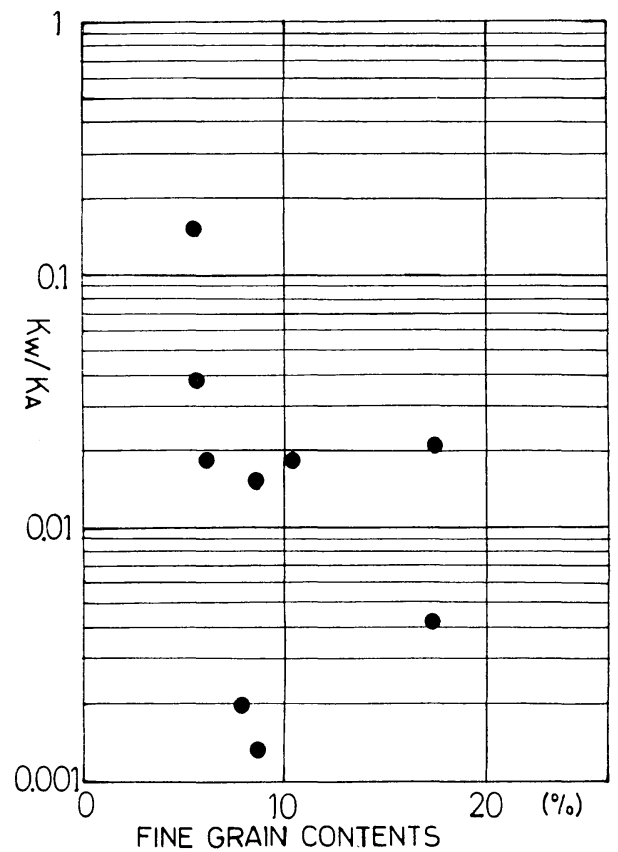

流れの主流において砂の堆積は厚く，かつ大きく乱れ， その拡がりとして周辺部においては比較的穏やかに堆積 した。そして砂岩の単層が厚くなると砂粒は粗く， sorting が悪くなる傾向がある。また本論文で述べたよ うに, 中央粒径が大きくなり, sorting が悪くなると孔 隙率は減少する。以上のことからも予想されるように, 砂岩単層が厚くなると孔陌率は減少する。そして流れの 主流である中心部の砂岩ほど孔隙率は低く，周辺部の砂 岩ほど孔隙率が高い傾向がある(第 4 図)。中心部・中 間部・周辺部の砂岩群が貯留岩となった時の容量は中心 部・中間部で大きく，周辺部では小さいが (第 1 表), これは層厚が大きく影響しているためであり，一定容積 の砂岩をとれば，周辺部の砂岩の容量が最も大きい。

浸透率は孔隙率が減少し， sorting が悪くなると減少 するが本地域の砂岩に関しては中央粒径との関連性はみ られない。また孔隙率の場合と同様に層厚が大きくなる と浸透率は減少し，中心部の砂岩ほど浸透率は低く，周 辺部の砂岩ほど浸透率は高い(第 8 図)。したがって中 心部に劣らず，中間部の砂岩群は貯留岩としての価值が 大きい。また周辺部の砂岩群は容積が小さいということ を除けば，貯留岩として最もよい性質をもっている。

“その 1”で述べたように，砂粒の配列状態には規則 性がみられ，堆積時の流れの方向に砂粒の長軸が平行に なる傾向がある。浸透率もそれにしたがい，流れに平行 方向で最大となり，成層面に平行で流れに直角方向がそ れに次ぎ，成層面に直角方向で最小になる傾向がある (第 2 表)。また同一方向への配列の規則性がはっきりみ られる砂岩ほど, 流れに平行方向と直角方向の浸透率の 比が大きい。つまり砂粒の配列状態にみられる規則性が 浸透率に方位性を与えている。

本邦の油・ガス田では，ここで対象としたような砂岩 が油層，ガス層をなす場合が少なくないと思われるが， 以上述べたことは，油・ガス鉱床の探鉱および開発（た とえば油・ガス井の坑井間隔）に際しても考慮すべきこ とと思われる。

今後の問題点として実際の油田・ガス田の貯留岩にお いてどのようになっているかを以上の結果を基にして検 討してみる必要がある。Carrigy ${ }^{1), 2)}$ は Athabasca の油 砂に打いて，粘土の含有量が油の含有量に大きく影響し ており，砂粒の粗いところが幾分油の含有量が多いと報 告しているが，実際に油層・ガス層を形成している貯留 岩については，2相または 3 相流体の存在を考えねばな らないので相対浸透率・毛管圧その他 petrophysical な 諸測定も試みる必要があろう。 


\section{引用交献}

1) Carrigy, M.A. (1959): The significance of a grain size classification of the sand of the McMurray Formation, Alberta, Proc. 5 th World Petrol. Congress, Sect. 1, paper 31, pp. 1-14

2) (1962): Effect of texture on the distribution of oil in the Athabasca oil sands, Alberta, Canada, Jour. Sed. Pet., Vol. 32, No. 2, pp. 312-325

3) Engelhard, W.H. (1960): Uber die Zusammenhäge zwischen Porosität, Permeabilität und Korngrosse. Heidelberger Beitrage zur Mineralogie und Petrographie, Bd. 2, pp. 477-491

4) (1960): Der Porenraum der Sedimente, Springer-Verlag, Berlin

5) Fraser, H.J. (1935): Experimental study of the porosity and permeability of clastic sediments, Jour. Geol., Vol. 43, No. 8, pp. 910-1010
6) Krumbein, W.C. and G.D. Monk (1943): Permeability as a function of the size parameter of unconsolidated sand, A.I.M.E. Trans., Petrol. Div., Vol. 151, pp. 153-163

7) Mast, P.F. and P.E. Potter (1963): Sedimentary structure, sand shape fabrics and permeability, Part I, Jour. Geol., Vol. 71, No. 4, pp. 441-471

8) (1963): - Part II, Jour. Geol., Vol. 71, No. 5, pp. 548-565

9) Pirson, S.J. (1958): Oil resservoir engineering, McGraw-Hill Book Co. Inc., New York

10) Rogers, J.J.W. and W.B. Head (1961): Relationships between porosity, median size and sorting coefficients of synthetic sand, Jour. Sed. Pet., Vol. 31, No. 3, pp. 467-470

11) Scheidegger, A.E. (1954): Directional permeability of porous media to homogeneous fluids, Geofisica Pure e Applicate-Milano, Vol. 28, pp. 65-90 